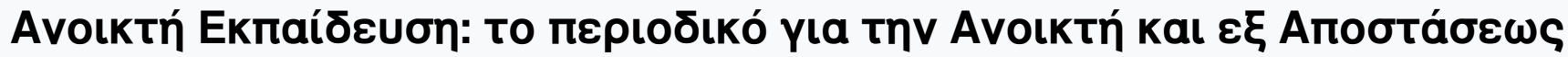

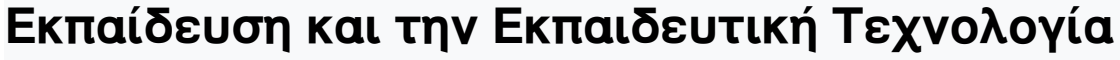

Tóp. 6, Ap. 1,2 (2010)

\section{Avoıкти́ Екпаíठєuơ}

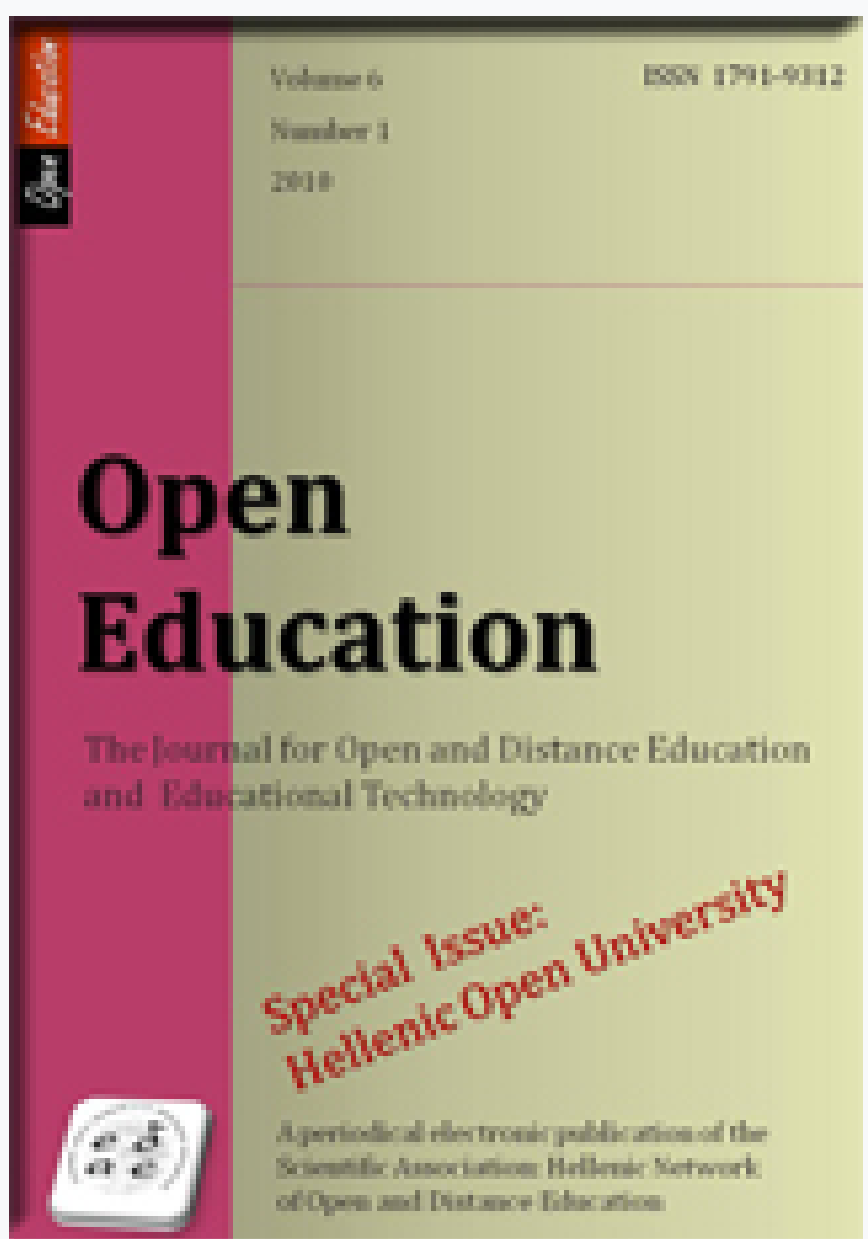

Exploiting Television in Open and Distance Learning: The Case of Undergraduate Courses in Cultural Studies at the Hellenic Open University

Gerasimos Koustourakis, Ioanna Pefani, Chris Panagiotakopoulos

doi: $10.12681 /$ jode. 9745

\section{Bıß入ıүрачıкń avaфopá:}




\title{
Exploiting Television in Open and Distance Learning: The Case of Undergraduate Courses in Cultural Studies at the Hellenic Open University
}

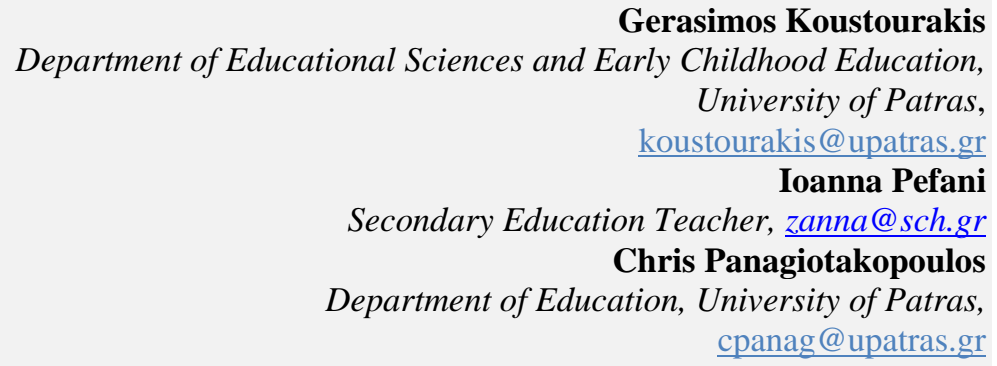

\begin{abstract}
This study aims to explore the level of integration television has in the educational process of the undergraduate courses of cultural studies of the Hellenic Open University (HOU), based on Bourdieu's theoretical standpoints. Acquisition of the research data was performed through a suitable questionnaire. In this research 394 students participated, from the courses «Studies in the European Culture» and «Studies in the Greek Culture». The principal findings of the research are the following: Television is not integrated in the institutional habitus of HOU, regarding the way distance learning is provided. Nevertheless, the majority of the students of the sample approached educational knowledge in a constructivistic way, finally integrating television, which comprises an element of modern humans' habitus, in personal learning tactics. Finally, the sample's students desire the exploitation of television from HOU, like many Hellenic Open Universities do, in an international level. They also expressed their desire that HOU will create television educational courses, focusing mainly on presentation of museums, archaeological sites, historical documentaries as well as teachings and lectures clarifying the confusing parts of their educational material.
\end{abstract}

Key words: Educational TV, technology, institutional habitus.

\section{Introduction}

The last decades have been characterized by the application of new, pioneering media for teaching and learning in education. The importance of mass media during the current postindustrial era, has contributed to this development, as well as the penetration of Information Computer Technologies (ICT) in the economical and educational sphere (Archer, 1996; Waters, 1996). The greatest influence of the mass media has been the spread of television (TV), which changed radically the way we perceive the world around us, since TV seems to possess an important role in places of work, entertainment and education, influencing the life of modern people on multiple levels (personal, social, cultural, political) (Giddens, 2002).

The aim of this research is the detection of the use and utilization of TV for the promotion of the learning process by students who attend the Hellenic Open University (HOU) undergraduate courses in cultural studies. The educational use of TV may be due to the demands of the educational material from specific study courses or it may be the result of HOU students' selfactivity in their effort to approach the scientific knowledge of the modules which they attend in their own way. 


\section{Theoretical framework}

The promotion of educational reforms in Greece, such as the establishment and function of the HOU, is characterized by the practice of educational borrowing (Bouzakis \& Koustourakis, 2002; Matthaiou, 1997 \& 2006). The point is the adoption of educational measures and practices that have been applied in other countries and are considered to be successful (Doury, 2009; Phillips, 2005). The regulation of the subjects of organization and provision of studies by the HOU was enacted under Law 2552/1997, influenced by the functional model of the British Open University (Lionarakis, 1998). In addition, for the acquisition of the know-how concerning the way to provide distance learning there was co-operation of the first Managing Committee of the institution with the leaders of the British Open University before the formation of the specific law (Koustourakis, 2006). In the HOU, which completed eleven years of continuous operation in the academic year 2009-2010 with the provision of undergraduate and graduate distance education, a specific institutional habitus was formed. That is, a special and separate way of operation from the conventional institutions academic culture of studies provision has been formed, which influences the consciousness of the teachers and students regarding their response to the prerequisites and demands that are put forward for the realization of the educational process (Reay, David \& Ball, 2005; Thomas, 2002). In the HOU, as in the case of the British Open University, the model for its function as an independent institution for the provision of third degree distant learning education is followed (Keegan, 2000: pp.160-63). Here, the learning process is connected to the teaching material, which is provided to the students by the educational institution and they are asked to work by themselves and study it according to a course schedule. Moreover, they are asked to elaborate written projects, join Group Advisory Meetings and apply the instructions of the tutor that are sent to them along with the correction of their written projects in order to cover their learning gaps and improve themselves continuously during their learning effort. Therefore, in the case of the HOU the student is given freedom to join the educational process through self-learning, which is supported by the institution through the intervention of the tutor.

To approach the educational process of the HOU we will utilize the views of Bourdieu (1989) for the structural constructivist approach of the educational reality. According to this, the educational practices are formed in the interactive framework of the institution through the dialectic interaction of the social structure (prerequisites and study demands put forward by the HOU), and the perceptions and cognitive patterns, which the students possess and apply during their study course (Bourdieu, 1989: pp.14-15; Bourdieu, 1990). In the HOU the role of the tutor, who undertakes the important responsibility of explaining, simplifying and supporting the institutional habitus of the institution to the students in their group (demands of the social structure). For this reason, tutors' instructive and advisory interventions aim to shape the consciousness of the students, concerning the provision of distance studying in the HOU, which seems to have an undoubtedly scientific and objective character. The intervention of the adult students of the HOU in the educational process is traced through strategies of self-learning, which they apply to the approach and understanding of the educational material. In the case of the HOU the provision of studies is mainly based on printed teaching material, while there also exists an effort to develop the use of the Internet for educational, informative and communicative reasons. Thus, the students of the institution are likely to seek further sources of information into which educational television programmes are also integrated. 
Nowadays, TV forms an integral part of everyday life for most people in the developed western world as it is used as a means of information and entertainment (Bourdon, 2000; Giddens, 2002). Thus, it influences the way people act socially, because the information, views and messages that are transmitted by the TV form, to a great degree, their perceptions, feelings and behaviour (Chiricos, Padgett \& Gertz, 2000; Marshall, Gorelly \& Biddle, 2006; Scherer, 2001). Therefore, the TV constitutes an element of the habitus of the modern man (Bourdieu, 1984 \& 1990). In addition, ICT use by young people is mainly by means of a computer monitor, which can also be used as a television screen, and is likely to show animations enriched with sound stimuli, films and educational software, which can include extracts from educational television programmes. Therefore, the use of the TV in connection with the Internet belongs to the habitus of the young people who come from middle social levels (Atkinson \& Nixon, 2005; Bourdieu, 1984; Buckingham, 2000). This fact can lead several students to the development of learning strategies, which lead to the exploitation of TV programmes for the extension of their knowledge for the academic field in which they are studying, or for the clarification and better understanding of knowledge which concerns a specific educational programme of distant studies.

The TV is used in the process of providing distance learning by many Open Universities, such as the British Open University, and the net of providing distance education "Nettuno" in Italy. In the last two, state television (BBC and RAI respectively) is used for the transmission of videorecorded lessons (Garito, 2001 \& 2004; Keegan, 1998; Shelton, 2001). This is so because it is thought that the TV can bring the school class or the university in contact with the world, by contributing positively to the distance learning effort of the students (Bates, 1988; Keegan, 1998; Wolf, 1998). In Turkey, the TV is considered to be one of the cornerstones for supporting the system of providing distance education (Saglik \& Ozturk, 2001). Furthermore, the TV seems to broaden the educational abilities of the people who live in deprived social and economical environments, and that is why it is used as an important educational medium by the Open Universities of India, Turkey, China and Africa (Carr-Chellman \& Zhang, 2000; Saglik \& Ozturk, 2001; Tait, 1994; Vyas, Sharma \& Kumar, 2002). The advantages presented by TV for the provision of distance learning increase when its use in the educational process is combined with other means, such as the Internet and printed educational material (Bradley, 2003; Keegan, 1998).

The criticism that has been expressed regarding the exploitation of TV for distance education states that it can inhibit the development of human relations between educators and students (Eleytheriades \& Mantouvalou, 1985; Saglik \& Ozturk, 2001). Also, evidence has shown that the numerous pictures which are shown by the TV during the presentation of a subject, do not allow the students' understanding and imagination to work creatively, as they are not given the chance for mental extensions in regard to what they have observed (Bates, 1988). Also, the students do direct and obvious participation in the educational television programmes. For this reason feedback and bidirectional communication with the educator is not achieved, while the degree of understanding of the subjects that are presented cannot be checked (Vyas et al., 2002; Wolf, 1998). However, the problem of feedback can be confronted where the television programmes are accompanied by suitable printed educational material. As well as when a possibility for students to communicate with the educators is provided after the transmission of the specific programmes (Vyas et al., 2002).

In this project we will be occupied with the approach of the following research questions: 
1) Does the Hellenic Open University utilize television in the educational process for the provision of undergraduate cultural studies?

2) Do the HOU undergraduate students, on their own initiative, use television cultural modules in an attempt to approach the educational material and understand the scientific knowledge that corresponds to their studies?

3) What are the views of certain HOU undergraduate students concerning the prospect of using educational television programmes for cultural studies that are provided by the institution?

\section{Methodology}

The methodological tool that was used for the collection of information was a questionnaire which included open and closed questions. The choice of these specific types of question has the additional benefit of contributing the influence of certain factors on the formation of the perceptions and behaviour of the students on the investigation on the one hand, and, on the other, to gives participants the possibility to express, explain their experience and views freely (Cohen, Manion \& Morrison, 2008).

The research was carried out during the period January-March 2008 and the questionnaire was given to the students of Modules EPO 12, 20, 21, 31, 41, who belong to the undergraduate programme 'Studies in European Culture'. It was also distributed to the students of Modules ELP 12, 22, 31, who belong to the undergraduate programme 'Studies in the Greek Culture'. To test the questionnaire, a preview was given to 30 students, who attend one of the above modules, in order to fill it in and indicate anything that needed correcting (Faulkner et al., 1999). These students were not included in the sample. In total, 401 questionnaires were gathered, 7 of which were completed hastily, and for this reason they were not taken into consideration. Thus, the final sample of the research was represented by 394 students, who correspond to the $10.3 \%$ of the total population of the 3,823 students, who were enrolled in above modules. The average age of the sample was 37.7 years (13.5\% up to 30 years, $48 \%$ from $31-40$ years, $35.8 \%$ from $41-50$ years and $2.7 \%$ over 50 years). The largest percentage of the sample students were women (242 students, 61.4\%), lived in the region (221 students, 56.0\%), were married (234 students, 59.5\%) and belonged to middle social levels (341 students, $86.5 \%$ ). This is calculated because they work in the tertiary section of services (234 students, 59.4\%), are artists or art restorers (19 students, 4.8\%), are self-employed (19 students, 4.8\%), or are teachers (64 students, 16.2\%) (Giddens, 2002). Also in the sample housewives are included (27 women, 6.8\%), farmers (8 students, $2.0 \%$ ) and unemployed people (19 students, $4.8 \%$ ), who chose to study in the HOU to obtain a university degree, with the hope of improving their social status.

\section{Findings analysis: Discussion}

In Table 1 (source: www.eap.gr) the distribution of the undergraduate modules for the HOU programmes "Studies in the European Culture" and "Studies in the Greek Culture" is presented depending on the type of the educational, teaching material, which is provided to their students.

\begin{tabular}{ccc}
\hline Type of Material & $\begin{array}{c}\text { Studies in the Greek } \\
\text { Culture - Modules }\end{array}$ & $\begin{array}{c}\text { Studies in the European } \\
\text { Culture - Modules }\end{array}$ \\
\hline $\begin{array}{c}\text { Only printed teaching } \\
\text { material }\end{array}$ & 8 & 8 \\
$(57.14 \%)$ & $(61.54 \%)$
\end{tabular}


Combination of printed, audiovisual material and software

Combination of printed, audiovisual material with the use of television

Total of Modules
6

$(42.86 \%)$

0

$(0.0 \%)$

14

$(100 \%)$
5

$(38.46 \%)$

0

$(0.0 \%)$

13

$(100 \%)$

Table 1: Educational material in the undergraduate programmes of cultural studies at the HOU

From the study of the elements of Table 1 it appears that in the undergraduate programmes of culture studies there is an emphasis on the use of printed teaching material. Also, the TV is not incorporated in the educational process of the HOU, as it is with many of the Open Universities that operate in the international arena (Carr-Chellman \& Zhang, 2000; Keegan, 1998; Rani, 2006; Saglik \& Ozturk, 2001).

Figure 1 shows the ranking of the use of audiovisual and technological means by the students of the sample during their studies at the HOU. From the graph, it appears that the students use email and the Internet much more, which along with printed educational material form elements of the institutional habitus of the HOU for the provision of distance study. Moreover, students turn away from former audiovisual means, such as the tape and the video, although in several modules at the HOU there are additional educational materials (audiocassettes and videocassettes), which presupposed their use for its courses (Eurydice, 2006). Moreover, though the TV is not included by the HOU in the process of providing distance learning it appears that it is used on a permanent basis though to a small degree by several students of the institution.

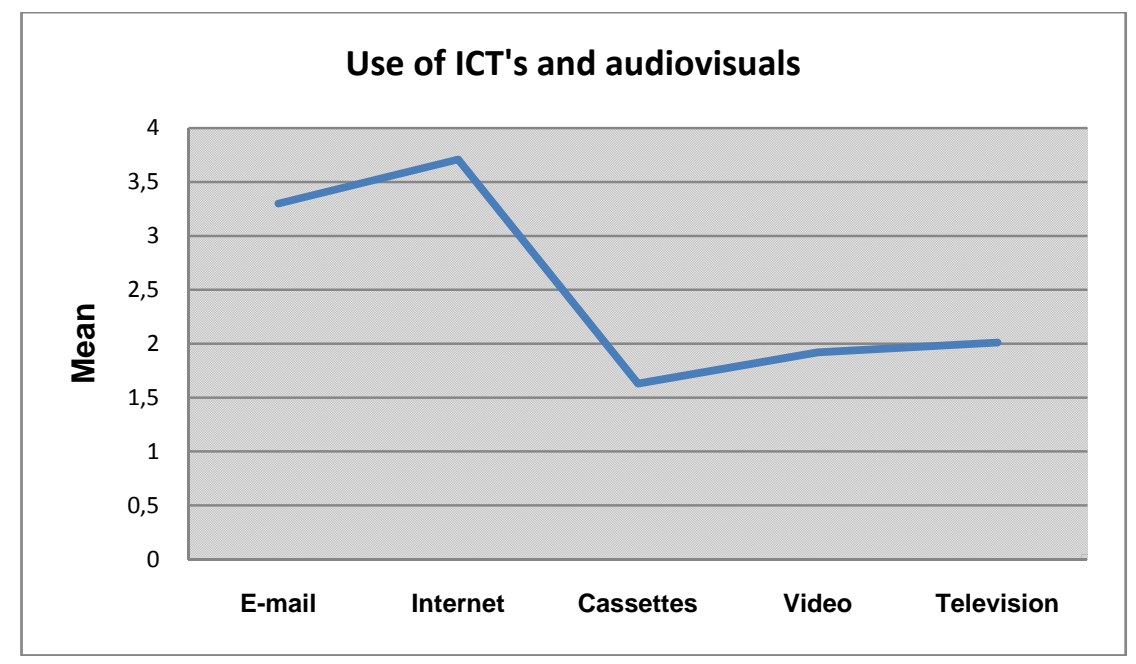

Figure 1: Hierarchical ranking of the use of audiovisual and technological means.

Investigating the students' perceptions about the necessity for using educational television in university distance learning studies, we examined primarily if they, themselves, sought to watch television programmes which referred to the subject matter of their studies. We noted that 237 students (60.15\%) sought to watch relevant television programmes and 157 students (39.85\%) did not. Therefore, we notice that the greatest part of the student sample, which falls into the 
middle social level, developed personal strategies in approaching knowledge, which are defined by their cultural status (Bourdieu, 1984 \& 1990), into which TV usage falls, and which constitutes a basic element of modern culture (Giddens, 2002).

Table 2 shows coded replies of the students regarding the reason why they chose or watch or not watch educational television programmes during their study in the cultural type modules of the HOU (an open type question).

\begin{tabular}{|c|c|c|}
\hline & Watching educational television programmes & References \\
\hline \multicolumn{3}{|c|}{ Positive Comments } \\
\hline 1. & Finding topics concerning subject matter & 60 \\
\hline 2. & Visualization of concepts & 51 \\
\hline 3. & Study support & 46 \\
\hline 4. & Understanding abstract concepts & 38 \\
\hline 5. & Visual contact offers immediacy & 18 \\
\hline 6. & Supplement of printed material & 12 \\
\hline 7. & Personal interest & 7 \\
\hline \multicolumn{3}{|c|}{ Negative comments } \\
\hline & $\begin{array}{l}\text { siderable subject matter that does not require any other form } \\
\text { rmation. }\end{array}$ & 16 \\
\hline & vision is obsolete & 6 \\
\hline & not consider the TV an interesting form of education & 5 \\
\hline \multicolumn{3}{|c|}{ Other comments } \\
\hline & rance of finding relevant educational television programmes & 94 \\
\hline & k of time due to work or other obligations & 27 \\
\hline & time does not fit in with television programmes & 9 \\
\hline
\end{tabular}

Table 2: Justification of the students answers about watching or not watching educational television programmes.

From the study of the elements of Table 2 it is evident that the greatest part of the student sample acted in a constructive way in order to approach knowledge (Bourdieu, 198 \&9, 1990) and tried to exploit the TV creatively so as to: a) obtain more knowledge concerning their object of studies (cases 1, 6 and 7 of positive comments: $20.0 \%$ of the students' sample); and b) better understand scientific knowledge, referring to the subject matter of the modules they attend, clarifying the difficult points or concepts (cases 2, 3, 4 and 5 of positive comments: $38.8 \%$ of the students' sample). In addition, the greatest proportion of students who did not use the TV reported that if they had known when the television programmes were being broadcast, in relation to the content of their studies, and if they could have afforded the required time, they would have attempted to exploit that specific means in their learning effort (cases other comments: $32.99 \%$ of the total 
sample). Therefore, the average number of students who were very negatively disposed to the educational use of the TV is small (6.85\%).

The opinions of the students referring to whether educational television should be used for distance learning were classified on the basis of the five-point Likert scale as follows: 29 students (7.36\%) not at all; 24 (6.09\%) a little; 74 (10.70\%) moderate; 137 (34.77\%) a lot; and 130 (32.99\%) a great deal. From the percentages for specific answers it is shown that the students have a very positive attitude regarding the use of educational television for distance learning. The percentages in 'a lot' and 'a great deal' are significantly higher than the corresponding percentages that refer to other rates. This is also confirmed by the average 3.80 and Standard Deviation (SD) 1.18, which refer to the specific question. These views of the students converge with the reality of TV usage by many universities abroad (Bates, 2005; Becker Reifschneider, 2006; Gulati, 2008; Latchem et al., 2008) and depart from the institutional habitus of the HOU regarding the way to approach educational material and present educational knowledge.

Where the students were asked whether they would like the HOU to incorporate the broadcasting of television educational programmes on the subject matter of the modules that they were attending, similar results were obtained. More specifically, 19 students (4.82\%) answered, not at all, 45 (11.42\%) a little, 85 (21.57\%) moderate, 128 (32.49\%) a lot, and $117(29.70 \%)$ a great deal. The average of the answers to this question was 3.71 and the SD was 1.15. Therefore, the greatest part of the students of the sample has a very positive attitude regarding the introduction of educational television in the HOU programme of cultural studies. Besides, it is a characteristic fact that the categories 'a lot' and 'a great deal' cover more than $60 \%$ of their answers. This fact shows the will of the specific students to have the existing institutional habitus of the HOU modified regarding the manner of providing cultural distance studies by incorporating educational television programmes into the educational process.

Table 3 shows the findings of the students' answers to the question how TV could influence their learning effort if it were used by the HOU as a means of supporting distance learning.

\begin{tabular}{|c|c|c|c|c|c|c|c|}
\hline $\begin{array}{c}\text { Contribution of the } \\
\text { television }\end{array}$ & None & A little & Medium & A lot & $\begin{array}{c}\text { A great } \\
\text { deal }\end{array}$ & Average & S.D. \\
\hline $\begin{array}{l}\text { Stimulation for } \\
\text { study }\end{array}$ & $\begin{array}{c}29 \\
(7.36 \%)\end{array}$ & $\begin{array}{c}43 \\
(10.91 \%)\end{array}$ & 67 (17.01\%) & $\begin{array}{c}165 \\
(41.88 \%)\end{array}$ & $\begin{array}{c}90 \\
(22.84 \%)\end{array}$ & 3.62 & 1.16 \\
\hline Attracting interest & $\begin{array}{c}45 \\
(11.42 \%)\end{array}$ & $\begin{array}{c}43 \\
(10.91 \%)\end{array}$ & 88 (22.34\%) & $\begin{array}{c}144 \\
(36.55 \%)\end{array}$ & $\begin{array}{c}74 \\
(18.78 \%)\end{array}$ & 3.40 & 1.23 \\
\hline $\begin{array}{l}\text { Improvement of the } \\
\text { quality of distance } \\
\text { learning }\end{array}$ & $\begin{array}{c}37 \\
(9.39 \%)\end{array}$ & $\begin{array}{c}59 \\
(14.97 \%)\end{array}$ & 85 (21.57\%) & $\begin{array}{c}144 \\
(36.55 \%)\end{array}$ & $\begin{array}{c}69 \\
(17.51 \%)\end{array}$ & 3.38 & 1.20 \\
\hline $\begin{array}{l}\text { Regulation of the } \\
\text { presentation of the } \\
\text { educational material }\end{array}$ & $\begin{array}{c}67 \\
(17.01 \%)\end{array}$ & $\begin{array}{c}69 \\
(17.51 \%)\end{array}$ & 98 (24.87\%) & $\begin{array}{c}131 \\
(33.25 \%)\end{array}$ & 29 (7.36\%) & 2.96 & 1.22 \\
\hline $\begin{array}{l}\text { Supporting weak } \\
\text { students }\end{array}$ & $\begin{array}{c}35 \\
(8.88 \%)\end{array}$ & $\begin{array}{c}43 \\
(10.91 \%)\end{array}$ & $80(20.30 \%)$ & $\begin{array}{c}151 \\
(38.32 \%)\end{array}$ & $\begin{array}{c}85 \\
(21.57 \%)\end{array}$ & 3.53 & 1.20 \\
\hline Psychological & 59 & 45 & $98(24.87 \%)$ & 155 & 37 (9.39\%) & 3.17 & 1.21 \\
\hline
\end{tabular}



support
$(14.97 \%)$
$(11.42 \%)$
(39.34\%)

Table 3: Anticipated results of the possible use of TV by the HOU

From the findings of Table 3, it is evident that students regard the use of TV by the HOU as bearing positive results in the distance learning studies that they follow. In fact, from their answers the following findings are highlighted; that is, that the connection of TV with the educational material would induce students to study more, because this would raise their interest in approaching the scientific knowledge and would, at the same time, improve the quality of the cultural type contents of the studies of the HOU. Also, it seems that the use of TV would contribute to the psychological support of the students because it would assist their learning effort, especially that of remote students, who are not doing very well in their studies, as they find it difficult to understand the subject matter of the printed educational material.

Table 4 shows the coded answers of the students to an open type question in which they could describe the content of the educational television programmes, which they regard as suitable for supporting the cultural content of their distance study. From the table it is obvious that the students wish the creation of educational television programmes would appear under a specific programme and would be repeated according to a predetermined schedule of projection, to help them to understand the difficult, but also the important, points of their educational material. Moreover, they wish the educational television programmes would include: guided tours of museums, ancient temples, Byzantine churches, important archeological sites; presentations of historic facts, discussions and lectures carried out by specialist scientists; videotaped courses and dramatization of texts, or presentation of theatrical performances (such as tragedies, comedies etc).

\begin{tabular}{lc}
\hline Desired programme content for educational television & References \\
\hline Historical documentaries and documentaries devoted to specific subjects & 79 \\
Visits to museums, galleries, churches, archeological sites & 73 \\
Television programmes for the development and explanation of difficult and & 56 \\
important aspects of the educational material & 36 \\
Videotaped courses & 23 \\
Lectures by specialist scientists & 8 \\
Dramatized themes & \\
\hline
\end{tabular}

Table 4: Desired programme content for educational television.

The opinions of the students concerning the help that can be offered to them by TV in understanding topics from their cultural studies programmes, which will bring them into contact with places and events that are difficult to access or not accessible to them at all (such as the guided tour of a foreign museum or a remote archeological site), are distributed as follows: not at all, 0 answers (0.0\%); a little, 29 (7.36\%); medium, 77 (19.54\%); a lot, 152 (38.58\%); and a great deal, 136 (34.52\%). The average of the answers to the specific question is 4.0 and the S.D. 0.91. Therefore, the students' acceptance of the prospective integration of TV into the educational process of the HOU is obvious. And this is so because $73.1 \%$ of the students, who 
answered 'a lot' and 'a great deal' think that the braodcasting of television programmes — which refer not only to remote and inaccessible to them places and sites, but also to unknown and obscure historic or social events, institutions or social conditions - would contribute to their understanding of the scientific knowledge that exists in the printed educational materials for the .modules they attend. It is a noteworthy fact that no student answered 'not at all'. Thus, even students negatively disposed towards the use of TV believe that it needs to be exploited, even for 'a while', in the educational process in order to help them know events and situations which they can not approach in any other way.

Table 5 presents the views of the students concerning the importance of the elements which can form a suitable television programme for distance learning.

\begin{tabular}{|c|c|c|c|c|c|}
\hline \multirow{2}{*}{$\begin{array}{l}\text { Elements of structure of a television } \\
\text { programme }\end{array}$} & \multicolumn{5}{|c|}{ Evaluation of the elements of structure } \\
\hline & 1 & 2 & 3 & 4 & 5 \\
\hline Good picture & 39 & 76 & 72 & 134 & 80 \\
\hline Good sound & 56 & 93 & 161 & 74 & 37 \\
\hline Interesting theme & 39 & 21 & 75 & 42 & 181 \\
\hline Good presenters & 96 & 131 & 32 & 95 & 48 \\
\hline Dramatization of the topic & 163 & 73 & 54 & 49 & 48 \\
\hline
\end{tabular}

Table 5: Evaluation of the elements of the structure of educational television programmes $(1=$ indifferent, $2=$ little interest, $3=$ medium interest, $4=$ great interest and $5=$ very great interest)

From Table 5 it appears that the students are interested primarily in the subject (topic) on which the educational television programmes is based. This finding expresses clearly their need for the visualization of the difficult and important points of the educational material. This is the reason why they pay less attention to good sound and even less to the presenters, or the dramatization of the subject matter, which they also wish to be approached through television.

Finally, Table 6 shows grouped student answers to an open type question referring to the advantages and disadvantages of the use of TV, which they consider to occur in the HOU's provision of TV for distance learning:

Advantages and disadvantages of the use of the television in distance education

References

Advantages:

Immediacy of contact with the object of study which becomes attractive

135

Access to places and situations that would not be visited by the students (for

example, museums, galleries etc)

86

Visualization of difficult points of the subject matter and shortening of the time of study

Motivation and guidance in the study, contribution to the consolidation of the subject matter 
Disadvantages:

Temporal and spatial limit

Cost for the implementation of this action by the HOU

Objective approach of reality is not ensured

Lessens the use of the printed material

Obsolete technology since there are computers

19

Table 6: Advantages and disadvantages of the use of the television by the HOU for the provision of distance education.

From Table 6, it is obvious that the students in the sample take into account as an important disadvantage of the use of the educational TV by the HOU, the possible circumvention of the principle for the provision of distant education, if the frequent repetition of the educational television programmes is not ensured.

Also, they are afraid that the exploitation of the TV by the HOU may increase the cost of educational services, which may affect them through the increase of their fees. Furthermore, objections are expressed by some of the students against the educational use of TV pointing out the risk of selective and unobjective presentation of some topics, or a reduction in printed educational material, on the grounds that the viewing of a picture attracts more people. Moreover, a small portion of the students (19 students, 4.8\%) thinks that the TV is an obsolete educational means compared to the educational exploitation of the Internet. However, these disadvantages seem to be offset by the advantages, which are mentioned by the greatest part of the student sample who accept the possible use of TV by the HOU. More specifically, the students agreed that television programmes can make the object of study immediately accessible and attractive, because they bring students into contact with unknown places and situations, which they cannot otherwise access. Also, they may help in the explanation and analysis of difficult points of the educational material, by resolving questions about obscure units or chapters, such as those which approach philosophical schools of thinking. Moreover, they believe that by watching suitable educational television programmes the student is urged to study the educational material and is assisted in their effort to understand, while the required study time is shortened. Finally, there is an important view expressed by a portion of the students (40 students, $10.15 \%$ ), that with the use of the educational TV the teacher comes closer to the student and, in this way, the possibility of abandoning their studies is reduced.

\section{Conclusions}

According to what we approached in this research project we come to the following results:

- Although the HOU adopted several elements of the British Open University regarding its organization and function, it did not formulate a culture of providing distance learning (institutional habitus) in which the educational use of television might be incorporated, as happens with the British Open University, but also with many Open Universities, which operate 
in an international space. Thus, the provision of undergraduate cultural studies programmes is based on printed educational material.

- The behaviour of the greatest part of the students on the cultural modules of the sample is differed from the institutional habitus of the HOU. This habitus is assisted by the action of the tutor, because the tutor attends and supports the students throughout their studies according to the institutional frame of operation of the HOU. Therefore, most students in undergraduate cultural studies programmes approaching educational knowledge, including television, in a constructive way, which is an element of most modern people in their personal learning strategies. In this way they tried to watch television programmes that they thought would be helpful for them to acquire more knowledge on the subject of their studies and to help them clarify and understand the difficult points of the modules in which they were enrolled.

- Finally, the greatest part of the students of the sample wishes to have the institutional constitution of the HOU amended regarding its way of providing distance learning, and requires the creation of television educational programmes which will focus mainly on presentations of museums, archeological sites, historical documentaries, art programmes, and videotaped teaching and lectures, and through which the difficult points of the subject matter will be clarified. Moreover, in the positively expected results of the incorporation of the educational television in the programmes of cultural studies of the HOU, falls the assistance of the student in approaching and understanding the educational material, reducing, at the same time, the required time for studying. The confrontation of the negative phenomenon of the dropouts of the students is expected also, because it appears that the educational television can bring the student closer to the educator. 


\section{References}

Archer, M. (1996). Culture and Agency. The Place of Culture in Social Theory. Cambridge: Cambridge University Press.

Atkinson, S., \& Nixon, H. (2005). Locating the subject: teens online @ ninemsn. Discourse: studies in the cultural politics of education, 26(3), 387-409.

Bates, A. (1988). Television, Learning and Distance Education. Journal of Educational Television, 14(3), 213-225.

Bates, A.W. (2005). Technology, E-Learning and Distance Education. London: Routledge.

Becker Reifschneider, M. (2006). Distance Education in Brazil and in the United States: a comparative review. ELearning, 3(4), 583-592.

Bourdieu, P. (1990). The Logic of Practice. Cambridge: Polity.

Bourdieu, P. (1989). Social space and symbolic power. Sociological Theory, 7(1), 14-25.

Bourdieu, P. (1984). Distinction. London: Routledge and Kegan Paul.

Bourdon, J. (2000). Live Television is Still Alive. Media Culture \& Society, 22(5), 531-556.

Bouzakis, S., \& Koustourakis, G. (2002). The Comparative Argument in the case of the Greek Educational Reform in 1997-1998. Comparative Education, 38(2), 155-169.

Bradley, J. (Ed.) (2003). The Open Classroom: Distance learning in and out of schools. London: Kogan Page.

Buckingham, D. (2000). After the death of childhood: Growing up in the age of electronic media. Cambridge: Polity Press.

Carr-Chellman, A.A., \& Zhang, Z. (2000). China's future with distance education. Rhetoric and realities. Information, Communication \& Society, 3(3), 303-312.

Chiricos, T., Padgett, K., \& Gertz, M. (2000). Fear, TV News, and the Reality of Crime. Criminology, 38(3), 755786.

Cohen L., Manion L., \& Morrison, K. (2008). Methodology of Educational Research. Athens: Metaixmio.

Doury, M. (2009). Argument Schemes Typologies in Practice: The Case of Comparative Arguments. In Van Eemeren, F.H. and Garssen, B. (eds), Pondering on Problems of Argumentation: Twenty Essays on Theoretical Issues (pp. 141-155). Amsterdam: Springer.

Eleytheriades, P., \& Mantouvalou, S. (1985). Modern Education and television. Athens: Diptycho.

Eurydice (2006). Eurybase. The Information Database on Education Systems in Europe. The organization of Greek educational system 2005/2006. European Commission. Retrieved May 5, 2009 from: http://eacea.ec.europa.eu/ressources/eurydice/eurybase/pdf/section/EL_EL_C6_18_3.pdf.

Faulkner, D., Swann, J., Baker, S., Bird, M., \& Carty, J. (1999). The child's development in social environments. Patras: Hellenic Open University.

Garito, M. A. (2004). NETTUNO-The university to watch, browse and surf on. Die Rolle des Telelearning: Europäische Erfahrungen Materialien, 87, 141-149.

Garito, M. A. (2001). The Telematic University: For the New Market of knowledge. In G. Van der Perre and P. Vandevelde (Eds.), The Wanderstudent 2000. The Wanderstudent of 1425 revived in virtual reality in 2000? Toward a European virtual university (pp. 121-133). Leuven: Leuven University Press.

Giddens, A. (2002). Sociology. Athens: Gutenberg.

Gulati, S. (2008). Technology-Enhanced Learning in Developing Nations: A review. The International Review of Research in Open and Distance Learning, 9(1). Retrieved May 15, 2009 from: http://www.irrodl.org/index.php/irrodl/article/view/477/1011.

Keegan, D. (1998). The two Modes of Distance Education. Open Learning, 13(3), 43-47.

Keegan, D. (2001). Basic elements of Open Distance Learning. Athens: Metaixmio.

Koustourakis, G. (2006). An attempt for formation of the framework for the organization and functioning of the Hellenic Open University: A sociological approach. In A. Lionarakis (ed.), Open and Distance Education. Elements of Theory and Praxis (pp. 42-77). Athens: Propobos.

Latchem, C., Abdullah, S., \& Xingfu, D. (2008). Open and Dual-Mode Universities in East and South Asia. Performance Improvement Quarterly, 12(2), 96-121.

Lionarakis, A. (1998). Institutions of Open Distance Learning. In D. Vergidis, A. Lionarakis, A. Lykourgiotis, V. Makrakis, C. \& Matralis, Open Distance Learning. Institutions and Functions (Volume A', pp. 143-243). Patras: Hellenic Open University.

Marshall, S.J., Gorelly, T., \& Biddle, S.J.H. (2006). A descriptive epidemiology of screen-based media use in youth: A review and critique. Journal of Adolescence, 29, 333-349.

Matthaiou, D. (1997). A Comparative Study of Education. Volume I. Athens: E.S.PAI.D.E.P.E.

Matthaiou, D. (2006). The comparative argument in educational politics. Sygritiki kai Diethnis Ekpaideytiki Epitheorisi, 6, 24-32. 
Phillips, D. (2005). Comparative education. An approach to educational inquiry. In C. Conrad \& R. C. Serlin (Eds.), The Sage handbook for research in education: Engaging ideas and enriching inquiry (pp. 279-296). London: Sage.

Rani, N.U. (2006). Educational Television in India. New Delhi: Discovery Publishing House.

Reay, D., David, M.E., \& Ball, S.J. (2005). Degrees of Choice. Stoke on Trent: Trentham Books.

Saglik, M., \& Ozturk, S. (2001). Television as an educational technology: Using television at open education faculty, Anadolu University. Turkish online journal of distance education, 2(1). Retrieved May 8, 2009 from: http://tojde.anadolu.edu.tr/tojde3/pdf/6.pdf

Scherer, K.R. (2001). Emotional experience is subject to social and technological change: extrapolating to the future. Social Science Information, 40(1), 125-151.

Shelton, J. (2001). 1971: U.K. Open University opens its doors. In History of Education: Selected Moments of the 20th Century. $\quad$ Retrieved April 28, 2009 from: http://fcis.oise.utoronto.ca/ daniel_schugurensky/assignment1/1971ukou.html

Tait, A. (1994). The end of innocence: critical approaches to Open and Distance Learning. Open Learning, 9(3), 2736.

Thomas, L. (2002). Student retention in higher education: The role of institutional habitus. Journal of Education Policy, 17(4), 423-442.

Vyas, R., Sharma, R., \& Kumar, A. (2002). Education Television in India', Turkish online journal of distance education, 3(4). $\quad$ Retrieved April 28, 2009 from: http://tojde.anadolu.edu.tr/tojde7/articles/educationalradio.htm

Waters, M. (1996). Daniel Bell. London and New York: Routledge.

Wolfe, T. (1998). Putting Interaction into Interactive Television. In Proceedings of the Annual Conference on Distance Teaching and Learning, August 5-7, 1998 (pp. 467-492). Madison, WI. 